\title{
Is Currency Depreciation or More Government Debt Expansionary? The Case of Thailand
}

\author{
Yu Hsing ${ }^{1}$ \\ ${ }^{1}$ Department of Management \& Business Administration, College of Business, Southeastern Louisiana University, \\ Hammond, Louisiana, United States \\ Email: yhsing@selu.edu
}

\begin{abstract}
Applying the aggregate demand and aggregate supply (AD/AS) model and based on a quarterly sample during 2001.Q1 - 2016.Q3, this paper finds that real GDP in Thailand has a positive relationship with the real effective exchange rate, government debt as a percent of GDP, labor productivity, the real oil price and a negative relationship with the real interest rate, real labor cost and the expected inflation rate. Hence, real appreciation of the Thai baht and sustainable increase in government debt as a percent of GDP would raise aggregate output.
\end{abstract}

Keywords: Exchange rate, government debt, labor productivity, labor cost, oil prices

\section{$1 \quad$ Introduction}

As the origin country of the 1997 Asian financial crisis, movements in the Thai baht exchange rate and its potential impact on aggregate output have continued drawing attentions. Before the Asian financial crisis, the exchange rate was pegged at 25 to 26 baht per U.S. dollar during 1995.Q4 - 1997.Q2. The Thai government could not continue to peg the exchange rate at this level in the long run due to substantial decrease in foreign exchange reserves to maintain the over-valued baht. After the Asian financial crisis, the THB/USD exchange rate rose to a high of 45.35 in 2001.Q2, declined to a low of 29.80 in 2013.Q1, and settled at 35.39 in 2016.Q4. Whether the $18.76 \%$ depreciation of the Thai baht versus the U.S. dollar during 2013.Q1 - 2016.Q4 may affect real GDP remains to be seen.

The Thai government pursued fiscal prudence as government debt as a percent of GDP was relatively low compared with some debt-ridden countries. Before the 2008 global financial crisis, Thai government debt as a percent of GDP dropped to a low of $21.4 \%$ in 2007.Q4. After the global financial crisis, the debt/GDP ratio reached a high of $26.99 \%$ in 2009.Q3 and continued to rise to $30.04 \%$ in 2016.Q4. Whether more government deficit spending and debt may affect real GDP needs to be further examined as it may affect the interest rate, private spending, the exchange rate, net exports and aggregate demand.

This paper attempts to examine the impacts of real depreciation or appreciation of the Thai baht and increase in government debt as a percent of GDP on aggregate output. The paper has several different aspects. First, the AD/AS model is employed in formulating the theoretical model. Second, in the shortrun aggregate supply function, labor productivity, real labor cost and the real oil price are included. Third, an advanced econometric technique is applied in estimating regression parameters.

\section{$2 \quad$ The Model}

The AD/AS model is a major macroeconomic model and has been employed in empirical work to estimate the impacts of changes in some exogenous variables such as the exchange rate, fiscal policy, monetary policy, etc. on the equilibrium real GDP or the inflation rate (Romer, 2012; Mishkin, 2012; Hubbard, O'Brien and Rafferty, 2014; Hsing, 2016). Suppose that aggregate demand is a function of the inflation rate, government spending, government taxes, the real interest rate and the real effective exchange rate and that short-run aggregate supply is determined by the inflation rate, labor 
productivity, real labor cost, the real oil price, the real effective exchange rate and the expected inflation rate. Extending Hsing (2016), we can express aggregate demand and short-run aggregate supply as

$$
\begin{gathered}
Y^{d}=f(\pi, G, T, R, \varepsilon) \\
Y^{s}=g\left(\pi, P, C, E, \varepsilon, \pi^{e}\right)
\end{gathered}
$$

where

$Y^{d}=$ aggregate demand,

$\Pi=$ the inflation rate,

$\mathrm{G}=$ government spending,

$\mathrm{T}=$ the real interest rate,

$\varepsilon=$ the real effective exchange rate (An increase means real appreciation of the Thai baht),

$\mathrm{P}=$ labor productivity,

$\mathrm{C}=$ real labor cost,

$\mathrm{E}=$ real oil price, and

$\pi^{e}=$ the expected inflation rate.

Aggregate demand has a positive relationship with government spending and a negative relationship with the inflation rate, government taxes, the real interest rate and the real effective exchange rate. Short-run aggregate supply has a positive relationship with the inflation rate, labor productivity and the real effective exchange rate and a negative relationship with real labor cost, the real oil price and the expected inflation rate.

Solving for $\mathrm{Y}$ and $\Pi$ in equations (1) and (2) simultaneously, we can express the equilibrium real GDP as

$$
Y^{*}=h\left(\varepsilon, G-T, R, P, C, E, \pi^{e}\right)
$$

To measure fiscal policy, we replace $\mathrm{G}-\mathrm{T}$ with government debt, which is the sum of government budget deficits:

$$
\begin{gathered}
Y^{*}=w\left(\varepsilon, D, R, P, C, E, \pi^{e}\right) \\
? \quad ?-+-?-
\end{gathered}
$$

According to comparative static analysis, the equilibrium real GDP is positively affected by labor productivity and negatively influenced by the real interest rate, real labor cost and the expected inflation rate. The impacts of the real effective exchange rate, government debt and the real oil price are unclear.

Real depreciation of a currency tends to help exports but increase the cost of imports and domestic inflation, and reduce aggregate demand and international capital inflows. Hence, the net effect is unclear. Findings of previous studies including Thailand in the sample are inconclusive. Currency depreciation is found to be contractionary (Morley, 1992; Kim, An and Kim, 2015), expansionary (Gylfason and Risager, 1983; An, Kim and Ren, 2014), contractionary in the short run and non-contractionary in the long run (Edwards, 1986; Kamin and Klau, 1998), and neutral (Bahmani-Oskooee, 1998; BahmaniOskooee, Chomsisengphet, and Kandil, 2002).

Many previous studies focus on whether rising government budget deficit or debt would raise the interest rate and cause the crowding-out effect. Empirical results are inconclusive. Barro (1974, 1989) shows that more government deficit/debt is found to have a neutral effect. McMillin (1986), Gupta (1989), Darrat (1989, 1990), Findlay (1990), and Ostrosky (1990) reveal that more government deficit/debt does not raise the interest rate. Several other studies argue that more government deficit/debt raises the interest rate and tends to cause a crowding-out effect (Feldstein, 1982; Hoelscher, 1986; Cebula, 1997; Cebula and Cuellar, 2010; Cebula, 2014a, 2014b; Cebula, Angjellari-Dajci, and Foley, 2014). Reinhart and Rogoff (2010) maintain that if government debt is more than $90 \%$ of GDP, it would reduce economic growth.

The traditional view of a higher real oil price is to shift short-run aggregate supply to the left and reduce the equilibrium real GDP. However, if the higher real oil price is caused by increased aggregate demand, there would be a positive effect on real GDP in the short run (Hamilton, 1996; Kilian, 2008a, 2008b). 


\section{$3 \quad$ Empirical Results}

The data were collected from the Bank of Thailand and the International Financial Statistics published by the International Monetary Fund. Real GDP is measured in millions of the baht. The real effective exchange rate is a weighted real exchange rate based on international trade with major countries. Government debt is measured as a percent of GDP. The real interest rate is represented by the difference between the nominal lending rate and the expected inflation rate. Labor productivity is an index number with 2001 as the base year. Labor cost is an index number with 2013 as the base year and includes overtime, bonus and others. It is adjusted by the CPI and expressed in real terms. The average crude oil price measured in the U.S. dollar is converted into the baht, adjusted by the CPI, and measured in real terms. Because real GDP shows seasonal patterns, three binary variables - S2, S3 and $\mathrm{S} 4$ - are added to the regression to represent the second, third and fourth quarters.

$$
Y^{*}=z\left(\varepsilon, D, R, P, C, E, \pi^{e}, S 2, S 3, S 4\right)
$$

The base regression represents the first quarter. The sample ranges from 2001.Q1 to 2016.Q3. The data for labor productivity and labor cost before 2001.Q1 are not available. The data for labor cost and productivity after 2016.Q3 have not been published. Descriptive statistics, correlation analysis, the ADF unit root test in level and first difference, and the ADF cointegration test on regression residuals are reported in Tables 1, 2, 3 and 4, respectively. In Table 4, because the test statistic is greater than the critical value in absolute values at the $1 \%$ level, we can reject the null hypothesis of a unit root in the regression residuals. Hence, these variables are cointegrated and have a long-term stable relationship.

Table 1. Descriptive statistics

\begin{tabular}{c|c|c|c|c|c|c|c|c}
\hline & $\mathrm{Y}$ & $\boldsymbol{\varepsilon}$ & $\mathrm{D}$ & $\mathrm{R}$ & $\mathrm{P}$ & $\mathrm{C}$ & $\mathrm{E}$ & $\pi^{e}$ \\
\hline Mean & 1929088 & 94.56 & 26.17 & 4.22 & 123.49 & 80.70 & 2298.33 & 2.37 \\
\hline Median & 1928791 & 96.52 & 26.49 & 4.10 & 122.90 & 76.36 & 2373.96 & 2.24 \\
\hline Maximum & 2530658 & 109.44 & 31.31 & 7.40 & 150.28 & 104.84 & 3927.16 & 5.86 \\
\hline Minimum & 1322688 & 80.73 & 21.43 & 0.77 & 92.90 & 69.28 & 1065.85 & -0.90 \\
\hline Std. Dev. & 331700 & 8.60 & 2.94 & 1.50 & 14.54 & 9.25 & 731.09 & 1.65 \\
\hline Skewness & -0.09 & -0.31 & 0.19 & 0.08 & -0.03 & 0.97 & 0.06 & -0.03 \\
\hline Kurtosis & 1.97 & 1.73 & 1.77 & 2.50 & 2.04 & 2.81 & 2.00 & 2.74 \\
\hline Jarque-Bera & 2.87 & 5.20 & 4.37 & 0.73 & 2.43 & 9.98 & 2.66 & 0.18 \\
\hline Probability & 0.24 & 0.07 & 0.11 & 0.69 & 0.30 & 0.01 & 0.27 & 0.91 \\
\hline Sum & $1.22 \mathrm{E}+08$ & 5957.4 & 1648.68 & 265.60 & 7779.63 & 5084.16 & 144795.0 & 149.39 \\
\hline Sum Sq. Dev. & $6.82 \mathrm{E}+12$ & 4586.2 & 537.39 & 140.33 & 13103.38 & 5302.20 & 33138851 & 168.97 \\
\hline & & & & & & & &
\end{tabular}

Table 2. Correlation analysis

\begin{tabular}{|c|c|c|c|c|c|c|c|c|}
\hline & $\mathrm{Y}$ & $\varepsilon$ & $\mathrm{D}$ & $\mathrm{R}$ & $\mathrm{P}$ & $\mathrm{C}$ & $\mathrm{E}$ & $\pi^{e}$ \\
\hline Y & 1.00 & 0.90 & 0.63 & 0.14 & 0.96 & 0.63 & 0.36 & -0.09 \\
\hline$\varepsilon$ & 0.90 & 1.00 & 0.51 & 0.04 & 0.87 & 0.47 & 0.49 & 0.07 \\
\hline $\mathrm{D}$ & 0.63 & 0.51 & 1.00 & 0.45 & 0.57 & 0.72 & -0.13 & -0.45 \\
\hline $\mathrm{R}$ & 0.14 & 0.04 & 0.45 & 1.00 & 0.13 & 0.47 & -0.42 & -0.93 \\
\hline $\mathrm{P}$ & 0.96 & 0.87 & 0.57 & 0.13 & 1.00 & 0.66 & 0.35 & -0.07 \\
\hline $\mathrm{C}$ & 0.63 & 0.47 & 0.72 & 0.47 & 0.66 & 1.00 & -0.23 & -0.38 \\
\hline$E$ & 0.36 & 0.49 & -0.13 & -0.42 & 0.35 & -0.23 & 1.00 & 0.49 \\
\hline$\pi^{e}$ & -0.09 & 0.07 & -0.45 & -0.93 & -0.07 & -0.38 & 0.49 & 1.00 \\
\hline
\end{tabular}


Table 3. ADF unit root tests

\begin{tabular}{|c|c|c|}
\hline & $\begin{array}{l}\text { Test statistic } \\
\text { Level }\end{array}$ & $\begin{array}{l}\text { Test statistic } \\
\text { First Difference }\end{array}$ \\
\hline $\mathrm{Y}$ & -1.2057 & $-5.4041^{*}$ \\
\hline$\varepsilon$ & -1.4109 & $-7.6606^{*}$ \\
\hline $\mathrm{D}$ & -0.9723 & $-8.0472^{*}$ \\
\hline $\mathrm{R}$ & -1.7464 & $-7.1336^{*}$ \\
\hline $\mathrm{P}$ & -0.9949 & $-5.0608^{*}$ \\
\hline $\mathrm{C}$ & -0.3129 & $-3.1975^{* *}$ \\
\hline $\mathrm{E}$ & -1.8902 & $-6.8813^{*}$ \\
\hline+2 & -1.6298 & $-3.2447^{* *}$ \\
\hline
\end{tabular}

Notes: * or ** indicates that they are significant at the $1 \%$ or $5 \%$ level.

Table 4. ADF cointegration test of the regression residuals

\begin{tabular}{l|l|l}
\hline Test statistic & Critical value & Significance level \\
\hline-4.1559 & -3.5504 & $1 \%$ \\
\hline & -2.9135 & $5 \%$ \\
\hline & -2.5945 & $10 \%$ \\
\hline & & \\
\hline
\end{tabular}

An analysis of the scatter diagram in Figure 1 shows that real GDP and the real effective exchange rate seem to have a positive relationship. Real appreciation of the Thai baht leads to a higher real GDP as the positive impact of more net exports tends to dominate the negative effects of higher domestic inflation and international capital outflows

Figure 2 indicates that real GDP and government debt as a percent of GDP also seem to exhibit a positive relationship with a few outliers during early years. More government debt as a percent of GDP raises aggregate output, suggesting that the crowding-out effect may be relatively small mainly due to relatively small government debt as a percent of GDP.

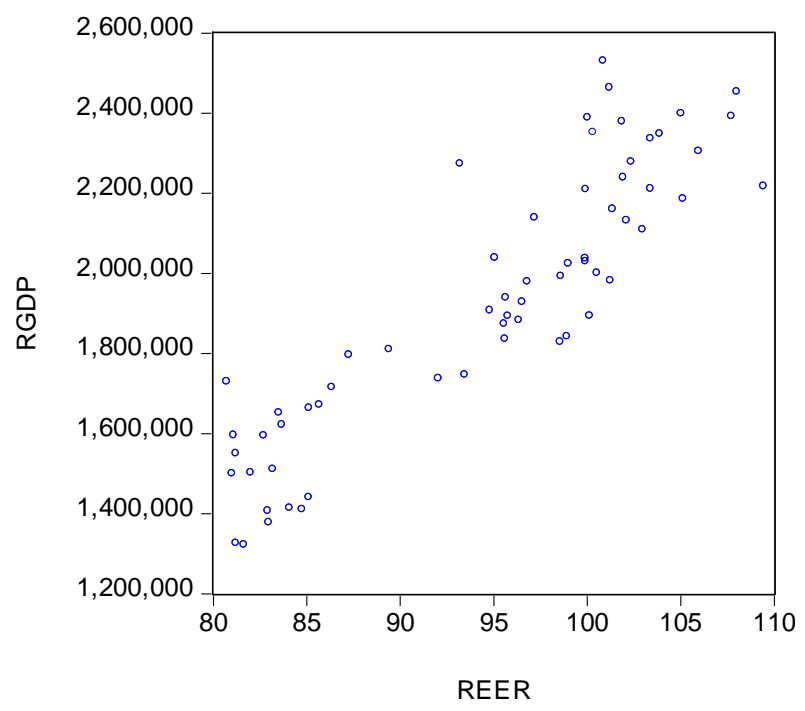

Figure 1. Scatter diagram between real GDP (RGDP) and the real effective exchange rate (REER) 


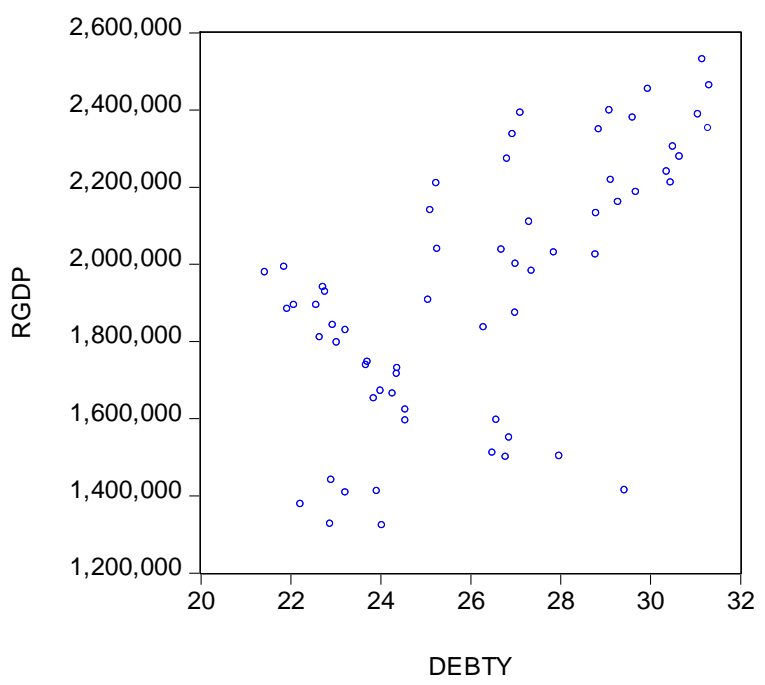

Figure 2. Scatter diagram between real GDP (RGDP) and government debt as a percent of GDP (DEBTY)

Table 5. Estimated regression of $\log ($ Real GDP) for Thailand

\begin{tabular}{l|l|l}
\hline Variable & Coefficient & z-Statistic \\
\hline C & 6.979942 & 58341.82 \\
\hline Log(Real effective exchange rate) & 0.445331 & 11514.20 \\
\hline Log(Government debt as a percent of GDP) & 0.116074 & 7.780945 \\
\hline Real lending rate & -0.020860 & -10.24210 \\
\hline Log(Labor productivity) & 1.120078 & 39328.31 \\
\hline Log(Real labor cost) & -0.091660 & -8.764435 \\
\hline Log(Real oil price per barrel) & 0.025233 & 7.696753 \\
\hline Expected inflation rate & -0.018526 & -11.00313 \\
\hline S2 & 0.009071 & 3.415844 \\
\hline S3 & 0.037364 & 7.779555 \\
\hline S4 & 0.051019 & 24.45808 \\
\hline R-squared & 0.965524 & \\
\hline Adjusted R-squared & 0.958894 & \\
\hline Akaike information criterion & -4.499572 & \\
\hline Schwarz criterion & -4.023320 & \\
\hline Methodology & EGARCH & \\
\hline MAPE & $2.052650 \%$ & \\
\hline Sample period & $2001 . \mathrm{Q} 1-2016 . \mathrm{Q} 3$ & \\
\hline Number of observations & \\
\hline
\end{tabular}

Notes:

All the coefficients are significant at the $1 \%$ level.

EGARCH stands for the exponential GARCH model.

MAPE is the mean absolute percent error.

Table 5 presents the estimated regression and related statistics. The EGARCH model is applied in empirical work. The EGARCH model has several advantages including fewer restrictions on the parameters, the conditional variance being a multiplicative function of the lagged error terms, and negative shocks producing more volatility than positive shocks. As shown, approximately $96.55 \%$ of the change in real GDP can be explained by the ten right-hand side variables. All the coefficients are 
significant at the $1 \%$ level. Real GDP has a positive relationship with the real effective exchange rate, government debt as a percent of GDP, labor productivity, the real oil price and three seasonal binary variables and a negative relationship with the real interest rate, real labor cost and the expected inflation rate. The mean absolute percent error of $2.0527 \%$ suggests that the forecast error is relatively small.

Specifically, a $1 \%$ real appreciation of the Thai baht would result in a $0.4453 \%$ increase in real GDP. If government debt as a percent of GDP rises $1 \%$, real GDP would increase $0.1161 \%$. Labor productivity has the largest impact in percent because a $1 \%$ increase in labor productivity would lead to $1.1201 \%$ increase in real GDP.

Several other versions have been considered. When the real effective exchange rate is replaced with the real exchange rate defined as the Thai baht per U.S. dollar times relative prices in the U.S. and Thailand, its negative coefficient is significant at the $1 \%$ level, and the value of R-squared is estimated to be $95.95 \%$. But, the negative coefficient of real labor cost becomes insignificant at the $10 \%$ level. As Thailand engages in international trade with many other countries, the real effective exchange rate seems to be a better measure than the real THB/USD exchange rate. If the real lending rate is replaced with the real government bond yield, its negative coefficient is significant at the $10 \%$ level, suggesting that the real lending rate may be a better measurement of the real interest rate. When the expected inflation rate is represented by the simple lagged inflation rate, its coefficient of -0.1810 is significant at the $1 \%$ level and is very close to the one reported in Table 1 , the value of R-squared is estimated to be $96.10 \%$, and other results are similar.

\section{Summary and Conclusions}

This paper focuses on the impacts of real depreciation or appreciation of the Thai baht and more government debt as a percent of GDP on aggregate output in Thailand. A simultaneous-equation model consisting of aggregate demand and short-run aggregate supply is applied. In the short-run aggregate supply function, labor productivity, real labor cost, the real oil price are considered. Real appreciation of the Thai baht, more government debt as a percent of GDP, a lower real interest rate, a higher labor productivity, a lower labor cost, a higher real oil price, or a lower expected inflation rate would help raise real GDP. In percent, labor productivity has the highest impact, followed by the real effective exchange rate and government debt as a percent of GDP.

Recent decrease in the real effective exchange rate of the Thai baht from 108.00 in 2015.Q1 to 100.31 in 2016Q3 would not help raise real GDP as it is positively affected by real appreciation of the Thai baht. Although more government debt as a percent of GDP has a positive impact on real GDP, fiscal discipline may be needed as the crowding-out effect is expected to take effect when government debt as a percent of GDP continues to rise to an unsustainable level. More investment in human capital would raise labor productivity and real output. Monetary easing to lower the real interest rate would reduce the cost of borrowing and provide incentives for households and firms to borrow and spend more. The current inflation target was set in the range of $2.5 \% \pm 1.5 \%$ in the medium term. The Bank of Thailand may need to consider reducing the upper range in order to reduce inflation expectations as a lower expected inflation rate tends to shift short-run aggregate supply to the right and increase real GDP.

\section{References}

1. Aisen, A. and D. Hauner, "Budget deficits and interest rates: A fresh perspective," Applied Economics, vol. 45, pp. 2501-2510, 2013.

2. An, L., G. Kim, and X. Ren, "Is devaluation expansionary or contractionary: Evidence based on vector autoregression with sign restrictions," Journal of Asian Economics, vol. 34, pp. 27-41, 2014.

3. Bahmani-Oskooee, M., "Are devaluations contractionary in LDCs?" Journal of Economic Development, vol. 23, pp. 131-144, 1998.

4. Bahmani-Oskooee, M., S. Chomsisengphet, and M. Kandil, "Are devaluations contractionary in Asia?" Journal of Post Keynesian Economics, vol. 25, pp. 69-82, 2002. 
5. Bahmani-Oskooee, M. and I. Miteza, "Are devaluations expansionary or contractionary? A survey article," Economic Issues, vol. 8, pp. 1-28, 2003.

6. Barro, R. J., "Are government bonds net wealth?” Journal of Political Economy, vol. 82, pp. 1095-1117, 1974.

7. Barro, R. J., "The Ricardian approach to budget deficits," Journal of Economic Perspectives, vol. 3, pp. 37-54, 1989.

8. Buchanan, James M., "Perceived wealth in bonds and social security: A comment" Journal of Political Economy, vol. 84, pp. 337-342, 1976.

9. Cebula, R. J., "An empirical note on the impact of the federal budget deficit on ex ante real long term interest rates, 1973-1995" Southern Economic Journal, vol. 63, pp. 1094-1099, 1997.

10.Cebula, R. J., "Impact of Federal Government Budget Deficits on the Longer-Term Real Interest Rate in the US: Evidence Using Annual and Quarterly Data, 1960-2013" Applied Economics Quarterly, vol. 60, pp. 23-40, 2014a.

11.Cebula, R. J., "An Empirical Investigation into the Impact of US Federal Government Budget Deficits on the Real Interest Rate Yield on Intermediate-Term Treasury Issues. 1972-2012" Applied Economics, vol. 46, pp. 3483-3493, 2014b.

12.Cebula, R. J. and P. Cuellar, "recent evidence on the impact of government budget deficits on the ex ante real interest rate yield on Moody's Baa-Rated Corporate Bonds" Journal of Economics and Finance, vol. 34, pp. 301$307,2010$.

13.Cebula, R. J., F. Angjellari-Dajci, and M. Foley, "An exploratory empirical inquiry into the impact of federal budget deficits on the ex post real interest rate yield on ten year treasury notes over the last half century" Journal of Economics and Finance, vol. 38, pp. 712-720, 2014.

14.Darrat, A. F., "Fiscal deficits and long-term interest rates: Further evidence from annual data," Southern Economic Journal, vol. 56, pp. 363-373, 1989.

15.Darrat, A. F., "Structural federal deficits and interest rates: Some causality and cointegration tests," Southern Economic Journal, vol. 56, pp. 752-759, 1990.

16.Edwards, S., "Devaluation and aggregate economic activity: An empirical analysis of the contractionary devaluation issue," (No. 412). UCLA Department of Economics, 1986.

17.Feldstein, M., "Perceived wealth in bonds and social security: A comment," Journal of Political Economy, vol. 84, pp. 331-336, 1976.

18.Feldstein, M., "Government deficits and aggregate demand," Journal of Monetary Economics, vol. 9, pp. 1-20, 1982.

19.Findlay, D. W., "Budget deficits, expected inflation and short-term real interest rates: Evidence for the US," International Economic Journal, vol. 4, pp. 41-53, 1990.

20.Gupta, K. L., "Budget deficits and interest rates in the US," Public Choice, vol. 60, pp. 87-92, 1989.

21.Gylfason, T. and M. Schmid, "Does devaluation cause stagflation?" Canadian Journal of Economics, vol. 16, pp. 641-654, 1983.

22.Gylfason, T. and O. Risager, "Does devaluation improve the current account?" European Economic Review, vol. 25, pp. 37-64, 1984.

23.Hamilton, J. D., "This is what happened to the oil price-macroeconomy relationship," Journal of Monetary Economics, vol. 38, pp. 215-220, 1986.

24.Hoelscher, G., "New evidence on deficits and interest rates," Journal of Money, Credit, and Banking, vol. 18, pp. 1-17, 1986.

25.Hsing, Y., "Is real depreciation contractionary? The case of South Korea," Economics Bulletin, vol. 36, pp. 19511958,2016

26.Hubbard, R. G., A. P. O'Brien, and M. P. Rafferty, Macroeconomics. NY, New York: Pearson, 2014.

27.Kalyoncu, H., S. Artan, S. Tezekici, and I. Ozturk, "Currency devaluation and output growth: An empirical evidence from OECD countries" International Research Journal of Finance and Economics, vol. 14, pp. 232-238, 2008.

28.Kamin, S. B. and M. Klau, "Some multi-country evidence on the effects of real exchange rates on output," FRB International Finance Discussion Paper 611, 1998.

29.Kilian, L., "The economic effects of energy price shocks," Journal of Economic Literature, vol. 46, pp. 871-909, 2008a. 
30.Kilian, L., "Not all oil price shocks are alike: Disentangling demand and supply shocks in the crude oil market" CEPR Discussion Paper No. 5994, 2008b.

31.Kim, G., L. An, and Y. Kim, "Exchange rate, capital flow and output: developed versus developing economies," Atlantic Economic Journal, vol. 43, pp. 195-207, 2015.

32.Lane, P. R. and J. C. Shambaugh, "Financial exchange rates and international currency exposures" American Economic Review, vol. 100, pp. 518-540, 2010.

33.Lau, E., S. A. Mansor and C. H. Puah, "Revival of the Twin Deficits in Asian Crisis-Affected Countries" Economic Issues, vol. 15(Part 1), pp. 29-53, 2010.

34.McMillin, W. D. "Federal Deficits and Short-Term Interest Rates" Journal of Macroeconomics, vol. 8, pp. 403422, 1986.

35.Mishkin, F. S., Macroeconomics: Policy and Practice. Boston: Addison-Wesley, 2012.

36. Mohammadi, H. and G. Moshrefi, "Fiscal policy and the current account: New evidence from four East Asian countries" Applied Economics Letters, vol. 19, pp. 167-173, 2012.

37.Morley, S. A., "On the effect of devaluation during stabilization programs in LDCs" Review of Economics and Statistics, vol. 74, pp. 21-27, 1992.

38.Nelson, D. B., "Conditional heteroskedasticity in asset returns: A new approach," Econometrica: Journal of the Econometric Society, vol. 59, pp. 347-370, 1991.

39.Nunnenkamp, P. and R. Schweickert, "Adjustment policies and economic growth in developing countries-Is devaluation contractionary?" Weltwirtschaftliches Archiv, vol. 126, pp. 474-493, 1990.

40.Ostrosky, A. L., "Federal government budget deficits and interest rates: Comment," Southern Economic Journal, vol. 56, pp. 802-803, 1990 .

41.Reinhart, C. M. and K. S. Rogoff, "Debt and growth revisited," MPRA Paper 24376. University Library of Munic, 2010.

42.Romer, D., Advanced Macroeconomics. New York, NY: McGraw-Hill, 2012. 